\section{Review of strategies to recruit smokers for smoking cessation: a population impact perspective}

\author{
Revisão sobre estratégias de captação de \\ fumantes: o olhar do impacto populacional
}

André Salem Szklo 1

\section{Introduction}

${ }^{1}$ Coordenação de Prevenção e Vigilância, Instituto Nacional de Câncer, Rio de Janeiro, Brasil.

Correspondência A. S. Szklo Divisão de Epidemiologia Coordenação de Prevenção e Vigilância, Instituto Nacional de Câncer.

Rua dos Inválidos 212,

3o andar, Rio de Janeiro, $R J$ 20231-020, Brasil. aszklo@inca.gov.br

\section{Abstract}

This paper reviews published articles describing several instruments used currently to "capture" the attention of smokers for quit-smoking interventions and emphasizes the distinction between the strategies used to reach eligible individuals and those used to recruit them for the proposed smoking cessation intervention. The search for articles was conducted using MEDLINE, PsychARTICLE, and LILACS. Key words for the search included recruitment, enrollment, reach, smoking cessation, quitline, and helpline mentioned in the abstracts and titles of the articles. Articles published in English, Portuguese, and Spanish through November 2006 that emphasized capture instruments related to different populations and specific interventions were included in this review. Twenty-nine studies met the inclusion criteria. Studies that used active and mixed strategies reached, on average, a smaller and less diverse possible number of eligible individuals and had greater participation proportions than those that used reactive strategies. Future studies are needed to evaluate the effectiveness of new associations between current interventions and reactive capture strategies, in view of the potential for increasing the population impact related to reactive capture.

Smoking Cessation; Patient Selection; Health Communication
There is a growing awareness that smoking control intervention programs should consider the complexity of cultural and socioeconomic situations that are part of the smokers' universe 1.

Several authors have pointed out that effectiveness of multiple interventions may be greater than the sum of their independent effectiveness levels 2,3,4. Effectiveness of smoking control programs is a function of numerous factors, including efficacy, adherence to the type of intervention or set of interventions, the target population's characteristics, and the tools employed to capture smokers 5 . Creativity and innovation are essential to deal with combinations of such complex variables 6,7. It is particularly important to understand that not all smokers are the same, and that certain types of smokers need to be "won over" as "potential clients" of an intervention program aimed at addressing their specific needs.

The purpose of this paper is to review several tools - both reactive and active - used to "capture" eligible smokers' attention for smoking control intervention programs. More specifically, this paper emphasizes the importance of reaching the target population and motivating it to receive the intervention. The actual efficacy levels of existing cessation interventions have been reviewed previously 8,9 and will not be discussed here. 


\section{Methods}

Potential studies were identified by searching three electronic databases: MEDLINE, compiled by the U.S. National Library of Medicine, for the period January 1, 1966, to November 30, 2006; PsycARTICLES, compiled by the American Psychological Association, from January 1, 1966, to November 30, 2006; and LILACS, compiled by the Latin American and Caribbean Center for Health Sciences Information, from January 1, 1982, to November 30, 2006. Only papers written in English, Spanish, or Portuguese were included in the search. The main objective of the search was to identify reports on existing recruitment strategies for smoking control programs/interventions. Search descriptors were broad, including a combination of the words recruitment, enrollment, reach, smoking cessation in abstracts or titles of papers, since the aim was to cover papers on all possible capture tools related to specific interventions applied to different populations. Recruitment strategies associated with "client-initiated" telephone interventions had a specific search descriptor (combination of words quitline, helpline, smoking in titles/abstracts of papers), in view of the possibility of their synergism with existing interventions in various national smoking control programs 10 .

The recruitment strategy itself appears to increase the number of participants 11 , independently of the duration of recruitment activities, the target population, and the type of smoking cessation intervention. Therefore, studies selected for this review were classified in three broad groups:

- Group 1: studies with reactive recruitment techniques, defined as strategies without realtime interpersonal contact with the researcher or service provider. These studies used television, radio, newspaper and magazine advertisements, billboards, press conferences, Internet, and mail approaches.

- Group 2: studies with active recruitment techniques, defined as strategies involving real-time interpersonal contact with the researcher or service provider. These studies used telephone, Internet, and face-to-face contacts with the researcher or health care professional.

- Group 3: studies adopting a combination of reactive and active recruitment techniques.

For each of these categories of studies, an attempt was made to obtain information that would allow calculating the following indices: (i) proportion of individuals contacted, defined as the number of eligible individuals successfully contacted during a predetermined period through a given communications channel, as a proportion of the total number of individuals in a given population at which the intervention was aimed; (ii) proportion of individuals recruited, defined as the number of individuals initially exposed to the proposed intervention as a proportion of all eligible individuals reached by the communications channel; (iii) proportion of the eligible population who participated in the study, a function of both the proportion contacted and that recruited, and defined as the number of individuals initially exposed to the study intervention as a proportion of the total number of individuals in a given population at which the intervention was aimed.

Article selection included two stages: (1) of the 161 total papers initially identified by the search, 65 had abstracts describing the recruitment strategy adopted and (2) after having reviewed the full texts of 65 initially selected abstracts, 29 met the present review's criteria, as follows: (i) papers on studies reporting on different recruitment strategies used in different populations and applying different types of interventions; (ii) papers reporting on the population that was reached, proportion of eligible smokers who were contacted, proportion recruited, and/or comparative profile of smokers initially exposed to the intervention. One of the articles included in the final selection was reviewed three times in the present paper, since it used different recruitment strategies in distinct populations. Two reviewers independently scanned abstracts and then read full texts of relevant articles $(n=65)$ to determine eligibility. Lack of agreement was resolved through discussion and consensus. Both reviewers independently abstracted data on the population that was reached, eligibility criteria, recruitment strategy, type of intervention, population participation proportion, and profile of individuals who were recruited. Of the 36 full texts' excluded articles, 32 (90\%) were conducted in the United States and only four in Eastern Europe between 1998 and 2006; 15 (42\%) of these studies used the same recruitment strategy as that adopted in similar populations and interventions reported in the 29 selected articles; however, 15 of the excluded texts did not describe either the profile of individuals initially exposed to the intervention $(n=7)$ or the total number of individuals reached by the communications channel $(n=8)$. The remaining $21(58 \%)$ were equally distributed among recruitment strategy groups and did not provide information about the total number of individuals in the intervention's target population. 


\section{Results}

Of the 29 studies selected for the present review, in $16(55.2 \%)$, recruitment was reactive (Group 1, Table 1), in $6(20.7 \%)$ it was active (Group 2, Table 2), and in 7 (24.1\%) a combination of reactive and active recruitment approaches was used (Group 3, Table 3).

\section{Proportion of individuals who were contacted}

In most studies $(89.7 \%$; $\mathrm{n}=26)$, the profile of the individuals contacted was broader than that of the intervention's target population. Seventeen studies $(65.4 \%)$ provided the percentages of eligible individuals among those who were

\section{Table 1}

Smoking control participation proportion according to the population reached, eligibility criteria, recruitment strategy, and type of intervention. Group 1 studies (reactive recruitment).

\begin{tabular}{|c|c|c|c|c|c|c|c|}
\hline $\begin{array}{l}\text { Author/Year } \\
\text { of publication }\end{array}$ & $\begin{array}{c}\text { Year } \\
\text { when the } \\
\text { study } \\
\text { was } \\
\text { conducted }\end{array}$ & $\begin{array}{l}\text { Population } \\
\text { reached }\end{array}$ & $\begin{array}{l}\text { Eligible } \\
\text { population } \\
\text { that was } \\
\text { reached }\end{array}$ & $\begin{array}{l}\text { \% eligible } \\
\text { individuals } \\
\text { among those } \\
\text { reactively reached } \\
\text { who were } \\
\text { interested in } \\
\text { participating } \\
\text { in study }\end{array}$ & $\begin{array}{l}\text { Recruitment } \\
\text { strategy }\end{array}$ & Intervention & $\begin{array}{l}\text { Population } \\
\text { participation } \\
\text { proportion * }\end{array}$ \\
\hline \multirow[t]{3}{*}{$\begin{array}{l}\text { Schmid } \\
\text { et al. 12/1989 }\end{array}$} & 1987 & $\begin{array}{c}\text { Resident sample } \\
\text { (Mankato, MN, USA); } \\
\mathrm{N}=8.5^{\star} 10^{3}\end{array}$ & $\begin{array}{c}\text { Smokers; } \\
N=2.7 * 10^{3}\end{array}$ & n.a. & Mail approach & $\begin{array}{c}\text { Delivery of help } \\
\text { material + financial } \\
\text { incentive option }\end{array}$ & 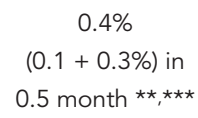 \\
\hline & & $\begin{array}{c}\text { Residents } \\
\text { (Fargo-Moorehead, } \\
\text { ND, USA); N }=10^{*} 10^{4}\end{array}$ & $\begin{array}{l}\text { Smokers; } \\
N=4 * 104\end{array}$ & & $\begin{array}{c}\text { Media \#+ } \\
\text { Mail approach }\end{array}$ & $\begin{array}{c}\text { Delivery of help } \\
\text { material + financial } \\
\text { incentive option }\end{array}$ & $\begin{array}{c}0.1-1.4 \%: \text { in } \\
0.5 \text { month **,\#\# }\end{array}$ \\
\hline & & $\begin{array}{l}\text { Residents } \\
\text { Bloomington, } \mathrm{MN} \\
\text { USA); } \mathrm{N}=8.0^{\star} 10^{4}\end{array}$ & $\begin{array}{c}\text { Smokers; } \\
N=3.0 * 10^{4}\end{array}$ & & $\begin{array}{c}\text { Media }+ \\
\text { mail approach }\end{array}$ & $\begin{array}{l}\text { Delivery of help } \\
\text { material + financial } \\
\text { incentive option }\end{array}$ & $\begin{array}{c}0.2-1.5 \% \text { in } \\
0.5 \text { month *,\#\# }\end{array}$ \\
\hline $\begin{array}{l}\text { McClure } \\
\text { et al. 16/2006 }\end{array}$ & 2004 & $\begin{array}{c}\text { Members of } \\
2 \text { hospitals } \\
\text { (MI and WA, USA); } \\
\mathrm{N}=60 * 10^{4}\end{array}$ & $\begin{array}{l}\text { Smokers; } \geq 10 \\
\text { cigarettes/day; } \\
21-70 \text { years; } \\
N=7 * 104\end{array}$ & 75.8 & $\begin{array}{l}\text { Mail } \\
\text { approach + } \\
\text { media }\end{array}$ & $\begin{array}{c}\text { Internet } \\
\text { counseling }+ \text { delivery } \\
\text { of nicotine } \\
\text { patches }\end{array}$ & $\begin{array}{c}3.1 \%(0.9+ \\
2.2 \%) \text { in } \\
11 \text { months } \S\end{array}$ \\
\hline $\begin{array}{l}\text { Ossip-Klein } \\
\text { et al. 19/1991 }\end{array}$ & 1987 & $\begin{array}{c}\text { Residents } \\
(10 \text { counties, NY, } \\
\text { USA); } N=62 * 10^{4}\end{array}$ & $\begin{array}{l}\text { Smokers; } \geq 10 \\
\text { cigarettes/day; } \\
N=5^{\star} 10^{4}\end{array}$ & n.a. & Media & $\begin{array}{l}\text { Delivery of help } \\
\text { material + phone } \\
\text { counseling }\end{array}$ & $\begin{array}{c}4 \%(0.9+1.5+ \\
1.6 \%) \text { in } 24 \\
\text { months } \S \S\end{array}$ \\
\hline $\begin{array}{l}\text { Ossip-Klein \& } \\
\text { Mclntosh 20/2003 }\end{array}$ & 2003 & $\begin{array}{l}\text { Residents (USA); } \\
N=27,000 * 104\end{array}$ & $\begin{array}{c}\text { Smokers; } \\
N=5,000 * 104\end{array}$ & n.a. & Media & $\begin{array}{c}\text { Phone } \\
\text { counseling }\end{array}$ & $\begin{array}{l}1.1-1.7 \% \text { in } \\
12 \text { months ** }\end{array}$ \\
\hline $\begin{array}{l}\text { Abdullah } \\
\text { et al. } 21 / 2004\end{array}$ & 2002 & $\begin{array}{c}\text { Residents } \\
\text { (Hong Kong, China); } \\
N=650^{\star} 10^{4}\end{array}$ & $\begin{array}{l}\text { Smokers; } \\
N=90 * 104\end{array}$ & 83.0 & $\begin{array}{l}\text { Media + } \\
\text { Internet }\end{array}$ & $\begin{array}{c}\text { Phone } \\
\text { counseling }\end{array}$ & $\begin{array}{c}0.1 \% \text { in } \\
18 \text { months }\end{array}$ \\
\hline Owen 22/2000 & 1997 & $\begin{array}{l}\text { Residents (England) } \\
\qquad N=5,000 * 104\end{array}$ & $\begin{array}{c}\text { Smokers; } \\
N=1,200 * 104\end{array}$ & 93.0 & Media & $\begin{array}{c}\text { Phone } \\
\text { counseling }\end{array}$ & 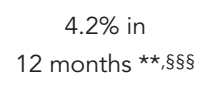 \\
\hline Platt et al. 23/1997 & 1992 & $\begin{array}{l}\text { Residents (Scotland); } \\
\qquad N=510^{\star} 10^{4}\end{array}$ & $\begin{array}{c}\text { Smokers; } \\
N=150 \star 104\end{array}$ & 92.0 & Media & $\begin{array}{c}\text { Phone } \\
\text { counseling }\end{array}$ & $\begin{array}{c}6 \% \text { in } \\
12 \text { months ** }\end{array}$ \\
\hline An et al. $24 / 2006$ & 2002 & $\begin{array}{c}\text { Residents } \\
(\mathrm{MN}, \mathrm{USA}) \\
\mathrm{N}=490 \star 104\end{array}$ & $\begin{array}{c}\text { Smokers; } \geq 5 \\
\text { cigarettes/day; } \\
\geq \text { 18years; } N=\text { n.a. }\end{array}$ & n.a. & Media & $\begin{array}{c}\text { Delivery of } \\
\text { nicotine patches + } \\
\text { phone counseling }\end{array}$ & $\begin{array}{l}\text { quadrupled in } \\
5 \text { months after } \\
\text { recruitment } \\
\text { strategy for } \\
\text { intervention }\end{array}$ \\
\hline
\end{tabular}

(continues) 
Table 1 (continued)

\begin{tabular}{|c|c|c|c|c|c|c|c|}
\hline $\begin{array}{l}\text { Author/Year } \\
\text { of publication }\end{array}$ & $\begin{array}{c}\text { Year } \\
\text { when the } \\
\text { study } \\
\text { was } \\
\text { conducted }\end{array}$ & $\begin{array}{l}\text { Population } \\
\text { reached }\end{array}$ & $\begin{array}{l}\text { Eligible } \\
\text { population } \\
\text { that was } \\
\text { reached }\end{array}$ & $\begin{array}{l}\text { \% eligible } \\
\text { individuals } \\
\text { among those } \\
\text { reactively reached } \\
\text { who were } \\
\text { interested in } \\
\text { participating } \\
\text { in study }\end{array}$ & $\begin{array}{c}\text { Recruitment } \\
\text { strategy }\end{array}$ & Intervention & $\begin{array}{l}\text { Population } \\
\text { participation } \\
\text { proportion * }\end{array}$ \\
\hline $\begin{array}{l}\text { Carrol \& } \\
\text { Rock 25/2003 }\end{array}$ & 1997 & $\begin{array}{c}\text { Residents } \\
\text { (Sydney and } \\
\text { Melbourne, Australia); } \\
\mathrm{N}=730 \star 10^{4}\end{array}$ & $\begin{array}{c}\text { Smokers; } \\
N=175^{\star} 10^{4}\end{array}$ & n.a & TV & $\begin{array}{c}\text { Phone } \\
\text { counseling }\end{array}$ & $\begin{array}{c}\text { n.a. in } \\
1.5 \text { month } \dagger\end{array}$ \\
\hline $\begin{array}{l}\text { Lando } \\
\text { et al. 26/1991 }\end{array}$ & 1988 & $\begin{array}{c}\text { Residents } \\
\text { (Bloomington, } \mathrm{MN}, \\
\text { USA); } \mathrm{N}=8^{\star} 10^{4}\end{array}$ & $\begin{array}{l}\text { Smokers; } \\
N=3^{\star} 104\end{array}$ & n.a. & $\begin{array}{c}\text { Media + mail } \\
\text { approach }\end{array}$ & $\begin{array}{c}\text { Delivery of help } \\
\text { material + financial } \\
\text { incentive option }\end{array}$ & $\begin{array}{c}7 \% \text { in } \\
8 \text { months t† }\end{array}$ \\
\hline $\begin{array}{l}\text { Cummings } \\
\text { et al. } 31 / 2006\end{array}$ & 2001 & $\begin{array}{c}\text { Residents } \\
\text { (Erie and Niagara, } \\
\text { NY, USA); } \\
N=30 * 10^{4}\end{array}$ & $\begin{array}{l}\text { Smokers; } \geq 5 \\
\text { cigarettes/day; } \\
\geq 18 \text { years; } \\
N=20 * 10^{4}\end{array}$ & n.a. & Media & $\begin{array}{c}\text { Delivery of } \\
\text { nicotine patches + } \\
\text { financial } \\
\text { incentive option }\end{array}$ & $\begin{array}{c}0.5 \% \text { in } \\
1 \text { month t+† }\end{array}$ \\
\hline $\begin{array}{l}\text { Otero } \\
\text { et al. } 50 / 2006\end{array}$ & 2001 & $\begin{array}{c}\text { Residents } \\
\text { (Rio de Janeiro, Brazil); } \\
N=410 * 10^{4}\end{array}$ & $\begin{array}{c}\text { Smokers; } \geq 5 \\
\text { cigarettes/day; } \\
\text { 19-59 years; } \\
N=50 * 104\end{array}$ & 61.4 & Media & $\begin{array}{l}\text { Group counseling } \\
\text { and delivery of } \\
\text { nicotine patches }\end{array}$ & $\begin{array}{l}0.2 \% \text { in } \\
1 \text { month }\end{array}$ \\
\hline $\begin{array}{l}\text { West } \\
\text { et al. 51/2006 }\end{array}$ & 2003 & $\begin{array}{l}\text { Internet group } \\
\text { sample (Canada, } \\
\text { France, UK, USA); } \\
\qquad \mathrm{N}=10^{\star} 10^{4}\end{array}$ & $\begin{array}{l}\text { Smokers; } \geq 5 \\
\text { cigarettes/day; } \\
35-60 \text { years; } \\
N=1 * 10^{4}\end{array}$ & 15.5 & E-mail & $\begin{array}{c}\text { Follow-up through } \\
\text { the Internet }\end{array}$ & $\begin{array}{c}\text { n.a. in } \\
0.5 \text { month } \ddagger\end{array}$ \\
\hline Etter 58/2006 & 2004 & $\begin{array}{l}\text { Internauts (USA); } \\
\mathrm{N}=16,000 * 10^{4}\end{array}$ & $\begin{array}{c}\text { Smokers; } \\
\mathrm{N}=3,000 * 10^{4}\end{array}$ & 80.0 & Internet & "Webpage" & 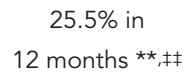 \\
\hline
\end{tabular}

n.a: not available; MI: Michigan; MN: Minnesota; ND: North Dakota; NY: New York; WA: Washington.

* Proportion of eligible individuals contacted was 100\% (except for the studies whose population participation proportion was impossible calculate and for Schmidt et al, related to the Mankato resident sample);

** Participation proportion calculated for adults only;

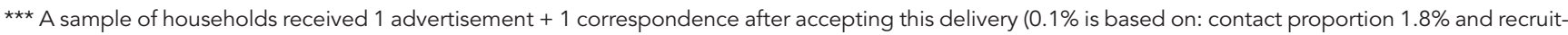
ment proportion $7.2 \%)$; another sample of households received correspondence directly from the program (0.3\% is based on: contact proportion $20.6 \%$ and recruitment proportion 1.6\%); considering a total of 14,540 households, 1.6 adults per household and $27 \%$ prevalence of adult smokers. Combined proportion of eligible individuals contacted was $22.4 \%$;

\# The media involves at least 2 of the following items: TV, radio, newspaper and magazine advertisements, billboards, pamphlets in public and private places, and press conferences;

\#\# Participation proportions according to different interventions (incentives): refundable deposit (0.1\%) and fixed rate (1.4\%); considering 1.6 adult per household and $27 \%$ prevalence of adult smokers;

\#\#\# Participation proportions according to different interventions (incentives): refundable deposit (0.2\%) and fixed rate (1.5\%); all households received 1 advertisement +1 correspondence from the program; considering 1.6 adult per household and $27 \%$ prevalence of adult smokers;

$\S$ Varied according to the recruitment strategy used: media: $0.9 \%$ and mail approach: $2.2 \%$; mail was delivered to a single sample of smokers; estimated eligible population represented by eligible population reached by the media;

$\S \S$ Varied according to communications channel recommended for the interested individual to keep in touch: $0.9 \%$ by letter, $1.5 \%$ through direct contact, and $1.6 \%$ by phone call;

$\S \S \S$ TV mostly targeted the 16-24-year age bracket; $40 \%$ of calls occurred in the first 3 months of study;

+ Used as outcome calls/TARP (target audience rating points) within 1 hour after TV broadcast; message targeted the 16-39-year age bracket;

t+ Considering 1.6 adults per household and $27 \%$ prevalence of adult smokers; incentive included winning a prize each month if abstinence in the previous month was confirmed;

t+† Conditioned by the availability of nicotine patches;

‡ Recruitment proportion 93.9\%;

$\ddagger \ddagger$ Considering that some $60 \%$ of eligible adult population uses the Internet and $5 \%$ of Internet users search the web themselves for information on how to quit. 
reached and accepted initial contact with the researcher or service provider, which varied from $15.5 \%$ to $93 \%$

Fifteen studies (52\%) succeeded in contacting populations with varying cultural, socioeconomic, organizational, and demographic characteristics as well as different levels of nicotine addiction. These studies, which reached smokers and non-smokers living in a given city or community, were mostly concentrated in Group 1 (81.3\%).

Generally speaking, studies in Groups 2 and 3 reached, on average, smaller eligible smoking populations $\left(1.6^{*} 10^{3}\right.$ and $2.5^{*} 10^{3}$ individuals, respectively) than Group 1 studies $\left(5.9^{*} 10^{6}\right.$ individuals).

Smoking control participation rate according to the population reached, eligibility criteria, recruitment strategy, and type of intervention. Group 2 studies (active recruitment).

\begin{tabular}{|c|c|c|c|c|c|c|c|}
\hline $\begin{array}{l}\text { Author/Year } \\
\text { of publication }\end{array}$ & $\begin{array}{c}\text { Year } \\
\text { when the } \\
\text { study } \\
\text { was } \\
\text { conducted }\end{array}$ & $\begin{array}{c}\text { Population } \\
\text { reached }\end{array}$ & $\begin{array}{l}\text { Eligible } \\
\text { population } \\
\text { that was } \\
\text { reached }\end{array}$ & $\begin{array}{c}\text { \% eligible } \\
\text { individuals } \\
\text { among those } \\
\text { actively reached } \\
\text { who were } \\
\text { interested in } \\
\text { participating } \\
\text { in study }\end{array}$ & $\begin{array}{c}\text { Recruitment } \\
\text { strategy }\end{array}$ & Intervention & $\begin{array}{l}\text { Population } \\
\text { participation } \\
\text { proportion * }\end{array}$ \\
\hline $\begin{array}{l}\text { Prochaska } \\
\text { et al. } 4 / 2004\end{array}$ & n.a. & 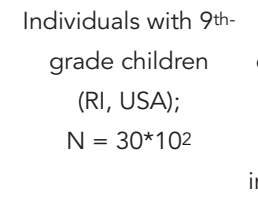 & $\begin{array}{c}\text { Smoker; sun } \\
\text { exposure without } \\
\text { protection; } \\
\text { inadequate fat } \\
\text { intake; } N=29 * 10^{2}\end{array}$ & 83.9 & $\begin{array}{c}\text { Real-time } \\
\text { phone contact }\end{array}$ & $\begin{array}{c}\text { Delivery of } \\
\text { help material }\end{array}$ & $84.0 \%$ ** \\
\hline Fava et al. 15/1995 & 1991 & $\begin{array}{c}\text { Sample of } \\
\text { residents (RI, USA); } \\
N=140^{\star} 10^{2}\end{array}$ & $\begin{array}{c}\text { Smokers, } \\
\text { 18-75 years old; } \\
N=52 * 102\end{array}$ & 36.3 & $\begin{array}{l}\text { Interpersonal } \\
\text { contact }\end{array}$ & $\begin{array}{c}\text { Delivery of } \\
\text { help material }\end{array}$ & $\begin{array}{c}\text { n.a. in } \\
9 \text { months *** }\end{array}$ \\
\hline $\begin{array}{l}\text { Griebel } \\
\text { et al. 29/1998 }\end{array}$ & n.a. & $\begin{array}{l}\text { Hospital patients } \\
\qquad \begin{array}{l}(\mathrm{OH}, \text { USA); } \\
\mathrm{N}=\text { n.a. }\end{array}\end{array}$ & $\begin{array}{l}\text { Smokers } \\
\geq 19 \text { years old; } \\
\mathrm{N}=1 * 10^{2}\end{array}$ & n.a. & $\begin{array}{l}\text { Interpersonal } \\
\text { contact during } \\
\text { admission }\end{array}$ & $\begin{array}{l}\text { Delivery of help } \\
\text { material + phone } \\
\text { and individual } \\
\text { counseling }\end{array}$ & $\begin{array}{l}58.0 \% \text { in } \\
6 \text { months }\end{array}$ \\
\hline $\begin{array}{l}\text { Ahluwalia } \\
\text { et al. 30/2002 }\end{array}$ & n.a. & $\begin{array}{l}\text { Hospital patients } \\
\qquad \begin{array}{l}\text { (GA, USA); } \\
N=19 * 102\end{array}\end{array}$ & $\begin{array}{l}\text { Smokers; } \geq 10 \\
\text { cigarettes/day; } \\
\geq 18 \text { years old; } \\
N=8 * 102\end{array}$ & 42.7 & $\begin{array}{c}\text { Interpersonal } \\
\text { in lobby }+ \\
\text { face-to-face with } \\
\text { attending physician }\end{array}$ & Video & $59.0 \%$ \\
\hline $\begin{array}{l}\text { Kendrick } \\
\text { et al. 44/1995 }\end{array}$ & 1988 & $\begin{array}{l}\text { Pregnant women } \\
\text { attending } 64 \text { clinics } \\
(\mathrm{CO}, \mathrm{MO} \text {, and } \mathrm{MD}, \\
\mathrm{USA}) ; \mathrm{N}=160^{*} 10^{2}\end{array}$ & $\begin{array}{l}\text { Smokers; } \\
\mathrm{N}=80 * 102\end{array}$ & 50.0 & $\begin{array}{l}\text { Interpersonal } \\
\text { contact }\end{array}$ & $\begin{array}{l}\text { Individual } \\
\text { counseling }+ \\
\text { delivery of } \\
\text { help material }\end{array}$ & $\begin{array}{l}68.4 \% \text { in } \\
24 \text { months }\end{array}$ \\
\hline $\begin{array}{l}\text { Schnoll } \\
\text { et al. 59/2004 }\end{array}$ & n.a. & $\begin{array}{l}\text { Smokers hospitalized } \\
\text { with brain, neck, or } \\
\text { lung cancer (PA, USA); } \\
\qquad N=2 * 10^{2}\end{array}$ & $\begin{array}{l}\text { Population } \\
\text { reached; } \\
N=2 * 10^{2}\end{array}$ & d.a. & $\begin{array}{c}\text { Real-time } \\
\text { phone contact }\end{array}$ & $\begin{array}{c}\text { Phone counseling } \\
\text { (reactive/active) }+ \\
\text { Nicotine patch delivery + } \\
\text { financial incentive }\end{array}$ & $\begin{array}{l}47.2 \% \text { in } \\
22 \text { months }\end{array}$ \\
\hline
\end{tabular}

n.a.: not available; d.a.: does not apply; CO: Colorado; GA: Georgia; MD: Maryland; MO: Missouri; OH: Ohio; PA: Pennsylvania; RI: Rhode Island.

* Proportion of eligible individuals who were contacted was 100\% (except for Fava et al. 15);

** Population reached consisted of all parents whose children were in the 9th grade and had already participated in another school study; $84 \%$ represent: total number of recruited eligible individuals / total of individuals with at least 1 risk factor;

*** It was not possible to calculate population participation proportion, since we did not know the total number of eligible smokers living in Rhode Island. We were able to calculate the recruitment rate (80\%) among those reached. 
Information on the initial target population (that would allow assessing the proportion of individuals who were contacted) was not available for three studies in Group 1 (18.8\%), one study in Group 2 (16.7\%), and two studies in Group 3 (28.6\%). Linan et al. 7 and Schmid et al. 12 were the only studies with proportions of contacted individuals that differed from $100 \%$ (43.6\% and $22.4 \%$, respectively).

\section{Recruitment tools}

In Group 1, only four studies (25\%) used a single reactive recruitment strategy (mail, e-mail, Internet, or TV). The other 12 studies (75\%) combined different reactive techniques, such as the use of several channels present in the category defined as "the media" (involving at least two of the following: TV, radio, newspaper or magazine advertisements, billboards, pamphlets in public and private places, or press conferences). In Group 2, four studies $(66.7 \%)$ used only one active recruitment strategy (interpersonal contact or real-time telephone contact). Of seven studies in Group 3, reactive and active strategies were mailings and real-time telephone calls $(\mathrm{n}=3)$ and mailings and inter-personal contacts $(n=3)$. McIntosh et al. 13 used three different strategies.

\section{Type of intervention}

Thirteen studies (44.8\%) used telephone counseling and five studies (17.2\%) offered individual or group counseling. Delivery of help material was offered to participants in 14 studies $(48.2 \%)$. One intervention each in Groups 2 and 3 delivered help material related to three and four specific interventions, respectively 4,7 . Nicotine patches were available in five studies (17.2\%). "Quit and win" interventions, consisting of different financial incentives, were offered in eight studies $(27.6 \%)$.

\section{Proportion of the eligible population who participated in the study intervention}

Generally speaking, studies in Group 1 had lower population participation proportions $(0.1 \%$ $25.5 \%)$ than in Groups $2(47.2 \%-84 \%)$ and 3 (5.5\%-65.3\%).

Three studies reached only a sample of eligible individuals: Schmid et al. 12 , in a study of Mankato residents, with a $0.4 \%$ participation percent over 0.5 months; Curry et al. 14 , using a "proxy" sample of the eligible population (children 10-12 years of age); and Fava et al. 15, in a study of Rhode Island residents, who failed to

Smoking control participation proportion according to the population reached, eligibility criteria, recruitment strategy, and type of intervention employed. Group 3 studies (reactive and active recruitment).

\begin{tabular}{|c|c|c|c|c|c|c|c|}
\hline $\begin{array}{l}\text { Author/Year } \\
\text { of publication }\end{array}$ & $\begin{array}{c}\text { Year } \\
\text { when the } \\
\text { study } \\
\text { was } \\
\text { conducted }\end{array}$ & $\begin{array}{c}\text { Population } \\
\text { reached }\end{array}$ & $\begin{array}{l}\text { Eligible } \\
\text { population } \\
\text { that was } \\
\text { reached }\end{array}$ & $\begin{array}{c}\% \text { eligible } \\
\text { individuals among } \\
\text { those actively } \\
\text { or reactively } \\
\text { reached who } \\
\text { were interested } \\
\text { in participating } \\
\text { in study }\end{array}$ & $\begin{array}{c}\text { Recruitment } \\
\text { strategy }\end{array}$ & Intervention & $\begin{array}{l}\text { Population } \\
\text { participation } \\
\text { proportion * }\end{array}$ \\
\hline $\begin{array}{l}\text { Glasgow } \\
\text { et al. 6/2006 }\end{array}$ & n.a. & $\begin{array}{l}\text { Smokers hospitalized } \\
\text { for surgery }(C O, \text { USA); } \\
\qquad N=1 * 10^{2}\end{array}$ & $\begin{array}{c}\text { Smokers; } \\
\geq 18 \text { years old; } \\
N=1 * 10^{2}\end{array}$ & 77.9 & $\begin{array}{c}\text { Mail approach + } \\
\text { real-time phone } \\
\text { contact }\end{array}$ & $\begin{array}{l}\text { Delivery of help } \\
\text { material + phone } \\
\text { counseling for } \\
\text { reduction or cessation }\end{array}$ & $\begin{array}{c}65.3 \% \text { in } \\
0.5 \text { month ** }\end{array}$ \\
\hline Linnan et al. 7/2002 & n.a. & $\begin{array}{c}\text { Workers in } 22 \\
\text { workplaces } \\
\text { (Providence, RI, USA); } \\
\mathrm{N}=43 * 10^{2}\end{array}$ & $\begin{array}{c}\text { Smokers; sun } \\
\text { exposure without } \\
\text { protection, } \\
\text { inadequate fat } \\
\text { intake; physically } \\
\text { inactive; } \\
N=35^{\star} 10^{2}\end{array}$ & t & $\begin{array}{l}\text { Mail approach + } \\
\text { real-time } \\
\text { phone } \\
\text { contact }\end{array}$ & $\begin{array}{c}\text { Delivery of } \\
\text { help material }\end{array}$ & $\begin{array}{c}23.8 \% \\
(11.1+12.7 \%) \\
\text { in } 1.5 \text { month *** }\end{array}$ \\
\hline
\end{tabular}

(continues) 


\begin{tabular}{|c|c|c|c|c|c|c|c|}
\hline $\begin{array}{l}\text { Author/Year } \\
\text { of publication }\end{array}$ & $\begin{array}{c}\text { Year } \\
\text { when the } \\
\text { study } \\
\text { was } \\
\text { conducted }\end{array}$ & $\begin{array}{l}\text { Population } \\
\text { reached }\end{array}$ & $\begin{array}{l}\text { Eligible } \\
\text { population in } \\
\text { that was } \\
\text { reached }\end{array}$ & $\begin{array}{c}\text { \% eligible } \\
\text { individuals among } \\
\text { those actively } \\
\text { or reactively } \\
\text { reached who } \\
\text { were interested } \\
\text { in participating } \\
\text { in study }\end{array}$ & $\begin{array}{c}\text { Recruitment } \\
\text { strategy }\end{array}$ & Intervention & $\begin{array}{l}\text { Population } \\
\text { participation } \\
\text { proportion * }\end{array}$ \\
\hline $\begin{array}{l}\text { Mclntosh } \\
\text { et al. 13/2000 }\end{array}$ & 1998 & $\begin{array}{l}\text { Residents } \\
(15 \text { counties, NY, } \\
\text { USA); } N=\text { n.a. }\end{array}$ & $\begin{array}{c}\text { Smokers; } \\
\geq 10 \text { cigarettes/day; } \\
\geq 50 \text { years old; } \\
N=\text { n.a. }\end{array}$ & y; & $\begin{array}{c}\text { Media \# + } \\
\text { mail approach + } \\
\text { interpersonal } \\
\text { contact }\end{array}$ & $\begin{array}{c}\text { Delivery of } \\
\text { help material }\end{array}$ & $\begin{array}{l}\text { n.a. in } 19 \\
\text { months \#\# }\end{array}$ \\
\hline $\begin{array}{l}\text { Curry } \\
\text { et al. 14/2003 }\end{array}$ & n.a. & $\begin{array}{l}\text { Sample individuals } \\
\text { enrolled in health } \\
\text { plan within last } \\
12 \text { months (OR } \\
\text { and WA, USA); } \\
N=61 * 102\end{array}$ & $\begin{array}{l}\text { Individuals } \\
\text { enrolled in } \\
\text { plan with } \\
\text { child aged } \\
10-12 \text { years; } \\
N=54^{\star} 10^{2}\end{array}$ & 84.7 & $\begin{array}{l}\text { Mail approach + } \\
\text { real-time } \\
\text { phone } \\
\text { contact }\end{array}$ & $\begin{array}{c}\text { Delivery of } \\
\text { help material + } \\
\text { phone } \\
\text { counseling }\end{array}$ & $\begin{array}{l}\text { n.a. in } 0.6 \\
\text { month \#\#\# }\end{array}$ \\
\hline $\begin{array}{l}\text { Tillgren } \\
\text { et al. 17/2000 }\end{array}$ & 1995 & $\begin{array}{l}\text { Smoking women } \\
\text { with children aged } \\
0-6 \text { years (Medical } \\
\text { District, Stockholm, } \\
\text { Sweden); N = 43*102 }\end{array}$ & $\begin{array}{l}\text { Population } \\
\text { reached; } \\
\mathrm{N}=43^{*} 102\end{array}$ & d.a. & $\begin{array}{l}\text { Mail approach + } \\
\text { real-time phone } \\
\text { contact }\end{array}$ & $\begin{array}{c}\text { Phone and } \\
\text { group counseling + } \\
\text { delivery of help } \\
\text { material + financial } \\
\text { incentive }\end{array}$ & $\begin{array}{c}5.5 \%(1.2+4.3 \%) \\
\text { in } 5 \text { months } \S\end{array}$ \\
\hline $\begin{array}{l}\text { Volpp } \\
\text { et al. 18/2006 }\end{array}$ & 2003 & $\begin{array}{c}\text { Hospitalized patients } \\
\text { (Philadelphia, PA, } \\
\text { USA); N }=4 * 10^{2}\end{array}$ & $\begin{array}{l}\text { Smokers; } \geq 10 \\
\text { cigarettes/day; } \\
\geq 18 \text { years old; } \\
N=2 * 10^{2}\end{array}$ & 44.3 & $\begin{array}{l}\text { Interpersonal } \\
\text { contact + mail } \\
\text { approach }\end{array}$ & $\begin{array}{c}\text { Individual } \\
\text { counseling + Delivery } \\
\text { of nicotine patches + } \\
\text { financial incentive }\end{array}$ & $\begin{array}{c}19.0-41.3 \% \\
\text { in } 9 \text { months } \S \S\end{array}$ \\
\hline $\begin{array}{l}\text { Glasgow } \\
\text { et al. 60/1993 }\end{array}$ & n.a. & $\begin{array}{l}\text { Hospitalized smokers } \\
\qquad \begin{array}{c}(\mathrm{OR}, \mathrm{USA}) \S \S \S ; \\
\mathrm{N}=22 * 102\end{array}\end{array}$ & $\begin{array}{l}\text { Population } \\
\text { reached; } \\
N=22 * 102\end{array}$ & d.a. & $\begin{array}{c}\text { Interpersonal } \\
\text { contact }+ \\
\text { newsletter }\end{array}$ & $\begin{array}{c}\text { Phone } \\
\text { counseling }\end{array}$ & $\begin{array}{c}14.2 \% \text { in } \\
33 \text { months }\end{array}$ \\
\hline
\end{tabular}

n.a.: not available; d.a.: does not apply; CO: Colorado; NY: New York; OR: Oregon; PA: Pennsylvania; RI: Rhode Island; WA: Washington.

* Proportion of eligible individuals who were contacted was 100\% (except for studies whose population participation proportion was impossible to calculate and for Linnan et al. 7):

** Phone contact occurred if the individual reached did not explicitly refuse such contact; $49.4 \%$ of those recruited chose cessation and $50.6 \%$ chose reduction;

*** Population reached consisted of workers who received mail and explicitly accepted phone contact (active consent) and those who received mail and did not explicitly refuse phone contact (reactive consent); proportion of eligible among individuals reached is calculated based on those who did not explicitly refuse phone contact; $11.1 \%$ (Contact proportion: $27.2 \%$; Recruitment proportion: $40.8 \%$ ) represents "total number of eligible individuals who passively accepted phone contact and were recruited / total of individuals with at least one risk factor"; $12.7 \%$ (contact proportion: $16.4 \%$; recruitment proportion: $77.4 \%$ ) represents "total number of eligible individuals who explicitly accepted phone contact and were recruited / total of individuals with at least one risk factor". Combined proportion of eligible individuals contacted was $43.6 \%$;

\# Media includes at least 2 of the following: TV, radio, newspaper and magazine advertisements, billboards, pamphlets in public and private places, and press conferences:

\#\# Of the total of eligible individuals who were recruited, $83.0 \%$ were through media, $16.3 \%$ through interpersonal contact with physician or relatives, $0.3 \%$ through mail (correspondence was sent to a sample of possible eligible individuals); recruitment rate was $51 \%$;

\#\# Sample consisted of recently enrolled individuals (previous 12 months) in two large public hospitals (Group Health Cooperative, Seattle, Washington, and Kaiser Permanent Northwest Division, Portland, Oregon, USA); recruitment strategy refers to individuals who received mail and did not explicitly refuse phone contact (reactive consent); recruitment rate was $77 \%$;

§ Of the total participation, $78.2 \%$ was through a recruitment strategy using mail and $21.8 \%$ from real-time phone contact; recruitment strategy was tailored in terms of content for the population reached (women with small children).

$\S \S$ Participation proportions according to different interventions: no financial incentives (19\%) and financial incentive (41.3\%);

$\S \S \S$ Population reached consisted of a sample of smokers participating in a cancer control program at a health center. 
provide enough information to assess the proportion of eligible individuals initially contacted, but in which the recruitment proportions were $77 \%$ in 0.6 months and $80 \%$ in nine months, respectively.

The proportion of the target population that participated in the interventions appears to have varied according to the different quitand-win programs and recruitment strategies $7,12,16,17,18,19$. Participation proportions for the seven interventions mediated by "quitlines", involving media recruitment strategies directed to different eligible populations, ranged from $0.1 \%$ to $6 \% 19,20,21,22,23,24,25$.

The study by Prochaska et al. 4 , offering three different interventions (related to smoking, diet, and sun exposure), showed an $84 \%$ participation percent for the three interventions combined; Linan et al. 7 included four different interventions (smoking, diet, sun exposure, and physical activity) and had a combined participation proportion of $23.8 \%$ over 1.5 months.

\section{Profile of participating smokers}

Of the 29 studies reviewed in the present paper, in $12(41.3 \%)$, data were available on the profile of smokers initially exposed to the intervention, thus allowing comparison with either the profile of the general smoking population or that of smokers who could not be persuaded to participate.

Compared with the general population of smokers, or with those who refused to participate in the study, in 9 studies (75\%), the group of smokers who agreed to participate showed a higher proportion of women and heavy smokers (> 20 cigarettes/day). In five studies (42\%), recruited smokers showed a higher proportion of individuals with more than a high school education. In Group 1 studies, average age appeared to be lower for quitlines as compared to other interventions.

\section{Discussion}

Proportions of the eligible population who participated in the studies selected for inclusion in this review varied widely $(0.1 \%$ to $84 \%)$, probably as a function of their wide variability in recruitment strategies, which has already been reported in other literature reviews 11,17.

\section{Reaching eligible participants and quality of recruitment strategy}

It is important not only to reach the target population, but also to motivate it to be exposed to the intervention (through recruitment). The proportions of eligible populations who agreed to interventions were higher in Groups 2 and 3, thus highlighting the importance of interpersonal recruitment strategies by telephone and direct contact.

Motivation to accept a given intervention is a function of external factors, such as recruitment strategies (e.g., Owen 22), interventions characterized by originality (e.g., Glasgow et al. 6), investment in combined recruitment strategies - seen in $69 \%$ of studies -, financial incentives (e.g., Schmid et al. 12, Volpp et al. 18), and organizational and structural contexts of the target communities (e.g., Lando et al. 26). Motivation may also be influenced by characteristics of individuals in the target population (e.g., ability to engage in self-improvement activities, being goal-oriented, or having better communication skills and more curiosity), thereby affecting likelihood of participation and the intervention's effectiveness 27 .

Multiple recruitment strategies and interventions appear to increase effectiveness beyond that of individual approaches. Since joint effectiveness is a function of the target population's characteristics, it is important that the profiles of those reached by the communications channel coincide (insofar as possible) with the economic and socio-cultural profile of potential beneficiaries 13,28 . In almost $90 \%$ of the studies we reviewed, subgroups of individuals reached by the recruitment strategies had different characteristics from those of the eligible population of smokers. In addition, the use of materials developed specifically to attract target smokers was only mentioned by three studies we reviewed 17,22,25.

Obviously, a balance must be found between the potential number of eligible individuals and the type of recruitment strategy adopted. Active recruitment can be very expensive and is thus more suitable for a smaller and less varied group of smokers, as observed in the studies summarized in Tables 2 and 3 (e.g., Griebel et al. 29 , Ahluwalia et al. ${ }^{30}$ ). The possibility of reaching larger smoking populations with more representative profiles, as seen in Group 1 studies (e.g., Ossip-Klein \& McIntosh 20), may increase the external validity of the results and increase their precision. Fava et al. 15 also showed that despite the low proportion of eligible individuals contacted, by using a telephone recruitment strategy in a sample of a heterogeneous group of eligible persons, the higher proportion of individuals recruited resulted in a greater ability to generalize results to a broader population.

Only three selected studies 12,19,31, all based on reactive recruitment strategies, described 
the relationship between recruitment strategy costs and increase in the proportion of the eligible population who participated in the study: Cummings et al. 31 included costs associated with marketing, purchasing, and mailing free nicotine patches and emphasized that the cost per smoker enrolled in the program was lower when compared with programs that did not publicize and offer nicotine patches. Schmid et al. 12 reported a positive association between eligible individuals' participation and total non-prize value of resource input (e.g. media promotion, labor, mailing list, printing, handling, and posting the recruitment materials). In addition, Ossip-Klein et al. 19 showed that investment in support structures offered to smokers to contact the researcher/provider also influenced the participation proportion.

Importantly, increasing investment in financial incentives and tailored interventions can increase both eligible individuals' participation, retention of individuals during intervention, and respective cessation rates. A review on the use and impact of incentives in population-based smoking cessation programs 32 showed that larger incentives were more effective in both influencing smokers' participation and motivating them to quit and remain smoking-free. Elixhauser 33 also reviewed the cost-effectiveness of smoking cessation methods and concluded that interventions specifically aimed at a particular subgroup appeared to be more cost-effective.

Thus, although the intervention's amount of promotional activity, support structure, and financial incentives appears to affect participation, information on cost per number of smokers enrolled and number of quitters should be also considered when interpreting population impact from smoking cessation interventions. According to Thyrian \& John 5 , population impact is a function of both recruitment strategy to motivate eligible individuals to participate, participant retention during intervention, and efficacy of the proposed intervention. These authors concluded that if active and reactive recruitment strategies are used to capture smokers for the same smoking cessation intervention, the former will result in greater population impact. However, costeffectiveness analysis may improve the abovementioned conclusions, due to the potential of reactive recruitment strategies for reaching (and recruiting) relatively large "audiences" of smokers at relatively low cost 13,33,34.

It is often difficult to assess the relationship between the ability to reach the target population and the effectiveness of the specific intervention, since the mere awareness of the intervention may also result in a change in smoking behavior 35 . In addition, some specific recruitment strategies, such as the use of media warning labels/images associated with the quitline number can be an intervention in itself 36,37. Combined recruitment strategies and interventions that reach a large segment of the target population of smokers such as the media (used in $75 \%$ of Group 1 studies) can also have an impact on non-smokers, either by persuading them not to start smoking or by fostering an anti-smoking social awareness that functions as a social barrier against smoking 38 .

It is thus important to remember that in the context where the recruit strategy is employed, the measures adopted by National or State Tobacco Control Programs (e.g., publicizing cigarettes' harmful effects or providing access to treatment) may act as possible confounders of the results presented in this article. Such measures may be important in terms of raising general awareness against tobacco use and can impact both the proportion of individuals recruited and cessation rates by increasing smokers' selfperceived risk and motivation to quit. Analyzing U.S. data $(80 \%$ of the selected studies were held in the United States), successful smoking cessation rates increased by $25 \%$ during the 1990 s, and States with comprehensive tobacco-control programs had greater cessation success, which may also be related to greater participation in smoking cessation programs 39 . For example, higher cessation rate, higher proportion of individuals attempting to quit, and lower smoking prevalence were observed in California than in tobacco-growing States (Kentucky, Tennessee, North and South Carolina, Virginia, and Georgia) 39,40 . These differences may be explained by the fact that California passed the first statewide ban on smoking in the workplace, restaurants, and bars in 1995, while there are still no such restrictions in tobacco-growing States. California also pioneered the Smokers' Helpline as part of its Tobacco-Control Program since 1993. In addition, the average price per pack in 1999 was $25 \%$ lower in tobacco-growing States than in California, and high cigarette prices are regarded as strongly related to proportions of smokers attempting to quit, as well as to actual cessation $35,39,41$.

\section{Target population initially exposed to intervention}

Multi-directed interventions 42 can improve the study's effectiveness, as in the impact formula developed by Velicer \& Prochaska ${ }^{43}$, revised for multiple eligibility profiles.

- Population impact related to a specific eligibility profile " $\mathrm{x}$ " for a given intervention: 
(1) Specific population impact (SPI) = possible total number of eligible individuals*proportion of participation*adherence* efficacy $_{\mathrm{x}}$.

- Population impact related to specific eligibility profiles " $\mathrm{x}+\mathrm{i}$ " for given intervention(s), assuming that proportion of participation, adherence, and efficacy for specific eligibility profile " $x$ " may positively or negatively interact with other recruitment strategies and/or interventions aimed at new specific eligibility profiles "i":

(2) Population impact $(\mathrm{PI})=[($ possible total number of eligible individuals*proportion of participa tion*adherence*efficacy) $\left.)_{\text {xinteraction }}\right]+[\Sigma i$ (possible total number of eligible individuals*proportion of participation*adherence* efficacy) ${ }_{\mathrm{i}}$.

- When "i" new specific eligibility profiles are considered, an increase in the population impact is defined as:

(3) Populationimpact increase $(\mathrm{PII})=\left[\Sigma^{\mathrm{i}}(\right.$ possible total number of eligibleindividuals* proportion of participation*adherence*efficacy $\left.)_{\mathrm{i}}\right]+[$ (possible total number of eligible individuals*proportion of participation*adherence*efficacy) $)_{\text {xinte }}$ raction - (possible total number of eligible individuals*proportion of participation*adhere nce* efficacy) $)_{\mathrm{X}}$.

Such multi-directed interventions may be aimed at specific subgroups of smokers - e.g., tailored according to different nicotine addiction stages, socio-cultural and organizational contexts - which will likely benefit from these joint interventions to a greater extent than they would from single interventions 44,45 . Thus, if we consider a hypothetical and more restricted eligibility profile " $x$ " for Groups 2 and 3 studies as the reference for the specific intervention, Group 1 studies that reached larger eligible populations with broad profiles $(\mathrm{x}+\mathrm{i})$ had an impressive potential to increase their population impact.

If the smoking population that is reached is exposed to risk factors other than smoking, the greater the number of aggregated risk factors, the greater will be the population's proportion for risk factors other than smoking and, consequently, a higher PI will be obtained, assuming that the population's participation proportion, adherence, and efficacy for smoking intervention remain unchanged or increase when there is interaction. The favorable cost-effectiveness of this type of recruitment strategy is clear, since many smokers are exposed to more than one risk factor, thus also making them eligible for interventions targeting other risk factors 2,46. In addition, the population defined for the proposed interventions does not necessarily have to only include smokers. In two studies reviewed here 4,7 , the interventions targeted nonsmokers with other risk factors (e.g., obesity, intensive sun exposure) and which, consequently, included a large number of individuals "at risk". Unfortunately, no information was available on the proportion of the eligible population who participated in the study for each specific intervention, since the authors provided only a combined proportion of all individuals "at risk" who were recruited for at least one of the specific interventions.

\section{Profile of participating smokers}

The motivation to agree to a given intervention is a function of specific socio-cultural and economic factors. For example, the use of newspaper advertisements as a recruitment strategy is obviously expected to be less successful in a target population with a high illiteracy rate 21 . Approaching a population with low schooling can also involve problems related to informed consent may also occur. For example, Linan et al. 7 observed that after receiving an initial letter, individuals with less schooling were less likely to understand their right to explicitly refuse subsequent telephone contacts.

Table 4 shows that the average age of quitline users is lower than that of smokers recruited for studies involving active recruitment - which is consistent with previous literature highlighting the importance of recruitment strategies without interpersonal contact among younger individuals 47 . Greater participation by women and smokers with more advanced stages of nicotine addiction may reflect worse self-perceived health and greater perceived benefits of smoking cessation, as compared to men and light smokers $24,28,48,49$.

\section{Limitations}

It is not totally straightforward why smokers agree to participate in a given intervention. One problem in previous studies is the lack of information on anti-smoking policies and organizational and structural contexts of the target communities.

Another limitation of these studies is the difficulty in assessing the relationship between population impact and effectiveness of the recruitment strategy used for a given intervention, because awareness of the intervention among eligible individuals who are reached through the recruitment strategy may cause a change in smoking behavior even if they are not ultimately recruited for the study.

Several studies have compared the eligibility profile of study participants; who were recruited with that of smokers in general, overlooking that the profiles of study participants and smokers in general can differ (see, e.g., Otero et al. 50 and West et al. 51). 
Comparison of profiles between individuals recruited and the reference population.

\begin{tabular}{|c|c|c|}
\hline Author/Year of publication & Profile reference population & $\begin{array}{l}\text { Profile of individuals recruited } \\
\text { (higher proportion of) }\end{array}$ \\
\hline Linnan et al. 7/2002 & $\begin{array}{l}\text { Workers recruited by phone } \\
\text { through active consent }\end{array}$ & $\begin{array}{l}\text { Workers recruited by phone through reactive consent: } \\
\text { schooling } \leq \text { complete high school, higher mean age }\end{array}$ \\
\hline McClure et al. 16/2006 & Smokers recruited by mail & Smokers recruited through media: women, higher mean age \\
\hline Ossip-Klein et al. 19/1991 & Smokers from USA & Women, age $\geq 45$ years, schooling $\geq$ university, $\geq 25$ cigarettes/day \\
\hline Abdullah et al. 21/2004 & $\begin{array}{l}\text { Smokers from Hong Kong, } \\
\text { age } \geq 15 \text { years }\end{array}$ & $\begin{array}{c}\text { Women, age } \leq 39 \text { years, schooling } \geq \text { university degree, } \\
\qquad 20 \text { cigarettes/day }\end{array}$ \\
\hline Owen $22 / 2000$ & Smokers from England, age $\geq 15$ years & Women, age between $25-44$ years, consumption $\geq 20$ cigarettes/day \\
\hline Platt et al. 23/1997 & Smokers from England, age $\geq 15$ years & Women, age $\leq 44$ years, $\geq 20$ cigarettes/day \\
\hline An et al. $24 / 2006$ & $\begin{array}{l}\text { 1) Smokers from Minnesota } \\
\text { 2) Smokers who called before initiating } \\
\text { nicotine replacement therapy }\end{array}$ & $\begin{array}{l}\text { 1) Women, higher mean cigarettes/day, smokes } \\
\text { first cigarette } 5 \text { minutes after waking up } \\
\text { 2) Smokers who called after nicotine replacement therapy } \\
\text { introduction: stronger intention to give up in the next } 30 \text { days }\end{array}$ \\
\hline Ahluwalia et al. 30/2002 & $\begin{array}{l}\text { Contacted eligible patients who signed } \\
\text { informed consent and did not } \\
\text { return for randomization }\end{array}$ & $\begin{array}{c}\text { Eligible patients who signed consent and were randomized exposed to } \\
\text { intervention): women, higher mean age, (schooling } \geq \text { complete } \\
\text { high school, higher mean consumption of cigarettes/day }\end{array}$ \\
\hline Cummings et al. $31 / 2006$ & Smokers living in Erie and Niagara & Women, higher mean age, higher mean consumption of cigarettes/day \\
\hline Otero et al. 50/2006 & $\begin{array}{l}\text { Smokers from Rio de Janeiro; } \\
\geq 5 \text { cigarettes/day; } 19-59 \text { years }\end{array}$ & Women, age $\geq 40$ years, schooling $\geq$ graduation, $>20$ cigarettes/day \\
\hline West et al. 51/2006 & $\begin{array}{l}\text { Smokers from USA, Canada, and UK, } \\
\quad \geq 5 \text { cigarettes/day, 35-60 years }\end{array}$ & $\begin{array}{l}\text { USA and Canada: schooling } \geq \text { university. UK: smoke first } \\
\text { cigarette }<30 \text { minutes after waking up }\end{array}$ \\
\hline Schnoll et al. 59/2004 & $\begin{array}{l}\text { Reached eligible patients who } \\
\text { refused to participate }\end{array}$ & $\begin{array}{l}\text { Recruited eligible patients: higher mean consumption of } \\
\text { cigarettes/day, stronger intention to quit in next } 30 \text { days }\end{array}$ \\
\hline
\end{tabular}

One final limitation is that due to the large number of potential studies on the topics covered by this review, our search was restricted to studies published in English, Portuguese, and Spanish with abstracts that highlighted the importance of recruitment. However, using a systematic approach, we sampled $10 \%$ of the 96 abstracts identified by the search descriptors, all based on studies from 1987 to 2006, mainly in the United States (80\%), which did not clearly state the importance ascribed to recruitment strategy: we ranked the papers by publication year and month, from the oldest to the most recent, and then chose "every 9-article distance" and read the selected full texts. Among these 10 newly selected papers, eight $(80 \%)$ did not provide information on the total number of individuals in a given intervention's target population. In the remaining two that met the inclusion criteria for the present review, one used a mixed recruitment strategy and the other an active recruitment strategy 52,53. The new results obtained (data not shown) did not change the main conclusions pertaining to participation proportions and total number of eligible individuals who were contacted.

\section{Conclusions}

Greater population impact can be achieved through a combination of multi-directed interventions with different recruitment strategies so as to motivate the largest possible number and widest variety of eligible individuals.

The findings of the studies reviewed in this article suggest that the profile of the individuals contacted was broader than that of the intervention's target population. They also suggest that 
the recruitment strategy (or strategies) may not have been tailored to motivate specific target populations with different cultural, socioeconomic, organizational, and demographic characteristics or varying levels of nicotine addiction. Thus, there is a distinction between the strategy used to reach eligible individuals and that used to recruit them for the proposed intervention. For instance, although studies that used reactive recruitment strategies reached large and varied numbers of eligible individuals, they only moti- vated smaller and less varied groups of potential eligible individuals to participate.

In order to assess real population impact, further research is needed to examine the effectiveness of new combined recruitment strategies and interventions, such as those using the Internet and the media specifically tailored to youth 54,55 . It is also important that studies consider the implementation, dissemination, and maintenance of recruitment strategies and interventions while maintaining reasonable costs 56,57 .

\section{Resumo}

Este artigo revisou artigos publicados sobre diversos instrumentos empregados atualmente para "capturar" a atenção dos fumantes, ressaltando a diferença existente entre alcance e recrutamento da população elegível para intervenção proposta. Realizou-se uma busca nas bases MEDLINE, PsychARTICLE, e LILACS. Os descritores de busca combinaram as palavras recruitment, enrollment, reach, smoking cessation, quitline, $e$ helpline presentes nos resumos/títulos dos artigos. Artigos publicados em inglês, português e espanhol até novembro de 2006, que deram importância a instrumentos de captação empregados, associando os mesmos a populações diferentes e a intervenções específicas foram incluídos na revisão. Vinte e nove estudos atenderam os critérios de inclusão. Estudos que utilizaram estratégias ativas ou mistas alcançaram, em média, um menor e menos diversificado número possível de indivíduos elegíveis e obtiveram maior proporção de participação do que aqueles que utilizaram estratégias reativas. Estudos futuros são necessários para se avaliar a efetividade de novas associações entre as intervenções existentes e estratégias reativas de captação, dada a potencialidade de aumento do impacto populacional relacionada à captação reativa.

Abandono do Hábito de Fumar; Seleção de Pacientes: Comunicação em Saúde

\section{Acknowledgements}

The author wishes to thank Evandro da Silva Freire Coutinho, Beatriz Carlini, Eliana Fonseca, and Moysés Szklo for their assistance in the paper's preparation. 


\section{References}

1. Hastings G, McLean N. Social marketing, smoking cessation and inequalities. Addiction 2006 101:303-4.

2. Prochaska JJ, Velicer WF, Prochaska JO, Hall SM, Delucchi, K. Comparing intervention outcomes in smokers treated for single versus multiple behavioral risks. Health Psychol 2006; 25:380-8.

3. Glasgow RE, Lichtenstein E, Marcus AC. Why don't we see more translation of health promotion research to practice? Rethinking the efficacy-to-effectiveness transition. Am J Public Health 2003; 93:1261-7.

4. Prochaska JO, Velicer WF, Rossi JS, Redding CA Greene GW, Rossi SR, et al. Multiple risk expert systems interventions: impact of simultaneous stagematched expert system interventions for smoking, high-fat diet, and sun exposure in a population of parents. Health Psychol 2004; 23:503-16.

5. Thyrian JR, John U. Population impact - definition, calculation and its use in prevention science in the example of tobacco smoking reduction. Health Policy 2007; 82:348-56.

6. Glasgow RE, Gaglio B, France EK, Marcus A, Riley KM, Levinson A, et al. Do behavioral smoking reduction approaches reach more or different smokers? Two studies; similar answers. Addict Behav 2006; 31:509-18.

7. Linnan LA, Emmons KM, Fava JL, LaForge RG, Abrams DB. Challenges to improving the impact of worksite cancer prevention programs: comparing reach, enrollment, and attrition using active versus passive recruitment strategies. Ann Behav Med 2002; 24:157-66.

8. Stead LF, Perera R, Lancaster T. Telephone counselling for smoking cessation. In: The Cochrane Database Systematic Reviews, Issue 3, 2006. http:// www.mrw.interscience.wiley.com/cochrane/ clsysrev/articles/CD002850/frame.html (accessed on $02 / \mathrm{Feb} / 2007$ ).

9. Lancaster T, Stead LF. Self-help interventions for smoking cessation. In: The Cochrane Database Systematic Reviews, Issue 3, 2005. http://www. mrw.interscience.wiley.com/cochrane/clsysrev/ articles/CD001118/frame.html (accessed on 02/ $\mathrm{Feb} / 2007)$.

10. Borland R, Balmford J, Hunt D. The effectiveness of personally tailored computer-generated advice letters for smoking cessation. Addiction 2004; 99:369-77.

11. McDonald PW. Population-based recruitment for quit-smoking programs: an analytic review of communication variables. Prev Med 1999; 28:545-57.

12. Schmid TL, Jeffery RW, Hellerstedt WL. Direct mail recruitment to home-based smoking and weight control programs: a comparison of strategies. Prev Med 1989; 18:503-17.

13. McIntosh S, Ossip-Klein DJ, Spada J, Burton K. Recruitment strategies and success in a multi-county smoking cessation study. Nicotine Tob Res 2000; 2:281-4.

14. Curry SJ, Hollis J, Bush T, Polen M, Ludman EJ, Grothaus L, et al. A randomized trial of a familybased smoking prevention intervention in managed care. Prev Med 2003; 37(6 Pt 1):617-26.
15. Fava JL, Velicer WF, Prochaska JO. Applying the transtheoretical model to a representative sample of smokers. Addict Behav 1995; 20:189-203.

16. McClure JB, Greene SM, Wiese C, Johnson KE, Alexander G, Strecher V. Interest in an online smoking cessation program and effective recruitment strategies: results from Project Quit. J Med Internet Res 2006; 8. http://www.jmir.org/2006/3/e14/ (accessed on $02 / \mathrm{Feb} / 2007$ ).

17. Tillgren P, Eriksson L, Guldbrandsson K, Spiik M. Impact of direct mail as a method to recruit smoking mothers into a "quit and win" contest. J Health Commun 2000; 5:293-303.

18. Volpp KG, Gurmankin Levy A, Asch DA, Berlin JA, Murphy JJ, Gomez A, et al. A randomized controlled trial of financial incentives for smoking cessation. Cancer Epidemiol Biomarkers Prev 2006; 15:12-8.

19. Ossip-Klein DJ, Giovino GA, Megahed N, Black PM, Emont SL, Stiggins J, et al. Effects of a smoker's hotline: results of a 10-county self-help trial. J Consult Clin Psychol 1991; 59:325-32.

20. Ossip-Klein DJ, McIntosh S. Quitlines in North America: evidence base and applications. Am J Med Sci 2003; 326:201-5.

21. Abdullah ASM, Lam T-H, Chan SSC, Hedley AJ. Which smokers use the smoking cessation Quitline in Hong Kong, and how effective is the Quitline. Tob Control 2004; 13:415-21.

22. Owen L. Impact of a telephone helpline for smokers who called during a mass media campaign. Tob Control 2000; 9:148-54.

23. Platt S, Tannahill A, Watson J, Fraser E. Effectiveness of antismoking telephone helpline: follow up survey. BMJ 1997; 314:1371-5.

24. An LC, Schillo BA, Kavanaugh AM, Lachter RB, Luxenberg MG, Wendling $\mathrm{AH}$, et al. Increased reach and effectiveness of a statewide tobacco quitline after the addition of access to free nicotine replacement therapy. Tob Control 2006; 15:286-93.

25. Carroll T, Rock B. Generating Quitline calls during Australia's National Tobacco Campaign: effects of television advertisement execution and programme placement. Tob Control 2003; 12 Suppl 2:ii40-4.

26. Lando HA, Hellerstedt WL, Pirie PL, Fruetel J, Huttner P. Results of a long-term community smoking cessation contest. Am J Health Promot 1991; 5:420-5.

27. Curry SJ, Wagner EH, Grothaus LC. Evaluation of intrinsic and extrinsic motivation interventions with a self-help smoking cessation program. J Consult Clin Psychol 1991; 59:318-24.

28. Berman BA, Grosser SC, Gritz ER. Recruitment to a school-based adult smoking-cessation program: do gender and race/ethnicity make a difference? J Cancer Educ 1998; 13:220-5.

29. Griebel B, Wewers ME, Baker CA. The effectiveness of a nurse-managed minimal smoking-cessation intervention among hospitalized patients with cancer. Oncol Nurs Forum 1998; 25:897-902.

30. Ahluwalia JS, Richter K, Mayo MS, Ahluwalia HK, Choi WS, Schmelzle KH, et al. African American smokers interested and eligible for a smoking cessation clinical trial: predictors of not returning for randomization. Ann Epidemiol 2002; 12:206-12. 
31. Cummings KM, Fix B, Celestino P, Carlin-Menter S, O'Connor R, Hyland A. Reach, efficacy, and cost-effectiveness of free nicotine medication giveaway programs. J Public Health Manag Pract 2006; 12:37-43

32. Bains N, Pickett W, Hoey J. The use and impact of incentives in population-based smoking cessation programs: a review. Am J Health Promot 1998; 12:307-20.

33. Elixhauser A. The costs of smoking and the cost-effectiveness of smoking-cessation programs. J Public Health Policy 1990; 11:218-37.

34. Nelson DE, Gallogly M, Pederson LL, Barry M, McGoldrick D, Maibach EW. Use of consumer survey data to target cessation messages to smokers through mass media. Am J Public Health 200 Jun 28; [Epub ahead of print].

35. Zhu S-H, Anderson CM, Johnson CE, Tedeschi G, Roeseler A. A centralised telephone service for tobacco cessation: the California experience. Tob Control 2000; 9 Suppl 2:ii48-55.

36. Joossens L, Raw M. The Tobacco Control Scale: a new scale to measure country activity. Tob Control 2006; 15:247-53.

37. Popham WJ, Potter LD, Bal DG, Johnson MD, Duerr JM, Quinn V. Do anti-smoking media campaigns help smokers quit? Public Health Rep 1993; 108:510-3.

38. Hammond D, Fong GT, Zanna MP, Trasher JF, Borland R. Tobacco denormalization and industry beliefs among smokers from four countries. Am J Prev Med 2006; 31:225-32.

39. Messer K, Pierce JP, Zhu SH, Hartman AM, Al-Delaimy WK, Trinidad DR, et al. The California Tobacco Control Program's effect on adult smokers: (1) smoking cessation. Tob Control 2007; 16:85-90

40. Centers for Disease Control and Prevention. Cigarette smoking among adults - United States, 2003. MMWR Morb Mortal Wkly Rep 2005; 54:509-13.

41. Monteiro CA, Cavalcante T, Moura EC, Claro RM, Szwarcwald CL. Population-based evidence of a strong decline in the prevalence of smokers in Brazil (1989-2003). Bull World Health Organ 2007; 85:527-34.

42. Velicer WF, Prochaska JO, Redding CA. Tailored communications for smoking cessation: past successes and future directions. Drug Alcohol Rev 2006; 25:49-57.

43. Velicer WF, Prochaska JO. An expert system intervention for smoking cessation. Patient Educ Couns 1999; 36:119-29.

44. Kendrick JS, Zahniser SC, Miller N, Salas N, Stine J, Gargiullo PM, et al. Integrating smoking cessation into routine public prenatal care: the Smoking Cessation in Pregnancy Project. Am J Public Health 1995; 85:217-22.

45. Borland R, Balmford J, Hunt D. The effectiveness of personally tailored computer-generated advice letters for smoking cessation. Addiction 2004; 99:369-77.

46. Sherwood NE, Hennrikus DJ, Jeffery RW, Lando HA, Murray DM. Smokers with multiple behavioral risk factors: how are they different? Prev Med 2000; 31:299-307.
47. Gilbert H, Sutton S, Sutherland G. Who calls QUIT? The characteristics of smokers seeking advice via a telephone helpline compared with smokers attending a clinic and those in the general population. Public Health 2005; 119:933-9.

48. Lyna P, McBride C, Samsa G, Pollak KI. Exploring the association between perceived risks of smoking and benefits to quitting: who does not see the link? Addict Behav 2002; 27:293-307.

49. McKee SA, O'Malley SS, Salovey P, KrishnanSarin S, Mazure CM. Perceived risks and benefits of smoking cessation: gender-specific predictors of motivation and treatment outcome. Addict Behav 2005; 30:423-35.

50. Otero UB, Perez CA, Szklo M, Esteves GA, Pinho MM, Szklo AS, et al. Ensaio clínico randomizado: efetividade da abordagem cognitivo-comportamental e uso de adesivos transdérmicos de reposição de nicotina, na cessação de fumar, em adultos residentes no Município do Rio de Janeiro, Brasil. Cad Saúde Pública 2006; 22:439-49.

51. West R, Gilsenan A, Coste F, Zhou X, Brouard R, Nonnemaker J, et al. The ATTEMPT cohort: a multi-national longitudinal study of predictors, patterns and consequences of smoking cessation; introduction and evaluation of internet recruitment and data collection methods. Addiction 2006; 101:1352-61.

52. Mak YW, Loke AY, Lam TH, Abdullah AS. Predictors of the participation of smoking parents in a proactive telephone-based smoking cessation program. Addict Behav 2006; 31:1731-43.

53. Hennrikus DJ, Jeffery RW, Lando HA, Murray DM, Brelje K, Davidann B, et al. The SUCCESS Project: the effect of program format and incentives on participation and cessation in worksite smoking cessation programs. Am J Public Health 2002; 92:274-9.

54. Worden JK. Research in using mass media to prevent smoking. Nicotine Tob Res 1999; 1 Suppl 1: S117-21.

55. Bock B, Graham A, Sciamanna C, Krishnamoorthy J, Whiteley J, Carmona-Barros R, et al. Smoking cessation treatment on the Internet: content, quality, and usability. Nicotine Tob Res 2004; 6:207-19.

56. Hallfors D, Cho H, Sanchez V, Khatapoush S, Kim HM, Bauer D. Efficacy vs effectiveness trial results of an indicated "model" substance abuse program: implications for public health. Am J Public Health 2006; 96:2254-9.

57. Kolbe LJ. Increasing the impact of school health promotion programs: emerging research perspectives. Health Educ 1986; 17:47-52.

58. Etter JF. The internet and the industrial revolution in smoking cessation counselling. Drug Alcohol Rev 2006; 25:79-84.

59. Schnoll RA, Rothman RL, Lerman C, Miller SM, Newman H, Movsas B, et al. Comparing cancer patients who enroll in a smoking cessation program at a comprehensive cancer center with those who decline enrollment. Head Neck 2004; 26:278-86.

60. Glasgow RE, Lando H, Hollis J, McRae SG, La Chance PA. A stop-smoking telephone help line that nobody called. Am J Public Health 1993; 83:252-3.

Submitted on $05 /$ Jun/2007

Final version resubmitted on 24/Sep/2007

Approved on 30/Oct/2007 